\title{
Profile of renal trauma victims treated at a university hospital in Curitiba
}

\section{Perfil dos pacientes vítimas de trauma renal atendidos em um hospital universitário de Curitiba}

Cesar Augusto Broska Júnior'; André de Castro linhares'; André Montes Luz'; Carlos Roberto NaufeLúnior, tCBC-PR'; Mariana Santos de-Oliveira ${ }^{1}$; André luiz Benção ${ }^{1}$; Gabriela Veronese ${ }^{1}$.

\begin{abstract}
A B S T R A C T
Objective: to study the profile of victims of kidney trauma who underwent surgical and medical treatment in a hospital in Curitiba. Methods: we conducted a retrospective, analytical, quantitative, cross-sectional study of patients with renal trauma admitted to the Evangelical Hospital of Curitiba between February 2011 and January 2014. Results: participated in the study 38 patients, four women and 34, men with a mean age of 28.4 years. Most injuries (60.5\%) was due to closed mechanisms, especially motorcycle accidents. Injuries were treated conservatively in most cases. Patients who required surgical treatment had severe kidney damage or some other associated lesion, usually intra-abdominal. Hospital stay was lower in the conservative treatment group (10.8 days) compared with the surgical treatment one (18.8 days); mortality was also lower in the conservative treatment group (8.3\%) compared with the surgical (14.3\%). There were no deaths associated to kidney damage itself. Conclusion: patients with renal trauma in this study were young men, victims of motorcycle accidents, taking place during the night and early morning. Most injuries were treated conservatively.
\end{abstract}

Keywords: Wounds and Injuries. Kidney/injuries. Abdominal injuries. Multiple Trauma. Traumatology.

\section{INTRODUCTION}

$T^{\text {the }}$ he abdominal trauma has shown increased their rates in recent years and represents a diagnostic challenge in some situations where the physical examination is poor and obscured by neurological disorders. In such cases, the hemodynamic status, the mechanism of injury and a high rate of suspicion are important to the definition between surgical and conservative management ${ }^{1,2}$. The kidneys are located in the posterior region of the abdomen, in the retroperitoneum, between T12 and L3, being anterolaterally protected by a muscle-aponeurotic wall and the abdominal viscera, and posteriorly, by the last ribs and the para-vertebral muscular. This anatomical arrangement provides protection from external injuries, making renal trauma an uncommon condition in relation to other organs, although among the genitourinary viscera they are the most affected. Due to their anatomical arrangement, it is necessary that a large amount of energy cross through adjacent structures. Therefore, when present, renal lesions are indicative of injuries in other intra-abdominal components in blunt trauma. Thus, renal trauma accounts for approximately $10 \%$ of visceral lesions in abdominal trauma.

The affected population is predominantly made up of young men (20-30 years), subject to blunt trauma ( $80 \%$ of cases), from falls and traffic accidents, especially those involving motorcyclists ${ }^{3-5}$. There is no specific symptoms of renal trauma. Pain is not reliable. Being a retroperitoneal organ, there is little or no abdominal pain or signs of peritoneal irritation. A palpable flank mass is also rarely present. The most common clinical finding is hematuria, however, it is not specific and its absence does not exclude renal injury. The presence of lower rib fractures and high lumbar processes increases the possibility of renal injury. Diagnosis often occurs as a complementary exam finding, usually computed tomography, performed to investigate other related injuries, or in surgical explorations, indicated in general for other reasons $s^{5-7}$.

1 - General Surgery Service, Evangelical University Hospital of Curitiba, Curitiba, Paraná State, Brazil. 
In closed traumas, renal lesions are mild in most cases, which allows a conservative approach. Penetrating injuries are less common but usually cause more serious injuries and often require surgical approach, but can also be effectively treated conservatively, depending, for this, on a team with experience in trauma and continuous monitoring of the patient's hemodynamic status ${ }^{6,7}$.

This study evaluates the profile of patients with renal trauma treated at a trauma hospital in Curitiba.

\section{METHODS}

This is a quantitative, retrospective, analytical, cross-sectional study. We reviewed charts of patients with renal injury admitted to the Trauma Surgery Department of the Evangelical University Hospital of Curitiba (HUEC) between February 2011 and January 2014. We collected data related to age, gender, time and mechanism of injury, degree of found injury (stratified by Organ injury Scaling for Kidney trauma), diagnostic methods, associated injuries, therapeutic approach, clinical outcome and length of hospital stay. For the purpose of statistical calculations, we grouped renal lesions into minor lesions (grades 1 and 2) and major ones (grades 3, 4 and 5).

As for the period of the day when the trauma occurred, we divided the patients into four groups, defined as early morning (between 00:00 and 06:00 hours), morning (between 06:01 hours and 12:00 hours) afternoon (between 12:01 hours and 18:00) and evening (between 18:01 hours and 23:59). The topic "diagnostic method" was intended to indicate whether the identification of the injury was through imaging or during surgery. The associated lesions were stratified by body part and also the involvement of parenchymal or hollow organs in the case of abdominal cavity lesions.

We defined the initially administered treatment as surgical or nonsurgical. The patient undergoing laparotomy or some other intervention approach that did not involve the affected kidney was considered in the clinical treatment group.
The clinical outcomes comprised the patient discharge, death or conversion of an initially conservative treatment to a surgical one. In case of surgical treatment, we also specified the technique used (debridement, nephrorrhaphy, drainage, partial or total nephrectomy).

For a description of quantitative variables, we applied the mean, median, minimum, maximum and standard deviation. For summarization of qualitative variables, we used frequencies and percentages. For comparison of the types of approaches as to quantitative variables, we employed the Student's t test for independent samples and the nonparametric MannWhitney test. To evaluate the association between qualitative variables with the type of approach, we used the chi-square and Fisher's exact tests. For evaluation of the variables' normality, we applied the JarqueBera test. We considered $p$ values less than 0.05 as statistically significant. We analyzed data with the computer software IBM SPSS, v.20.

The study was approved by the Ethics in Research Committee of the Beneficent Evangelical Society of Curitiba, CAAE 39364114.7.0000.0103, Opinion 908,938

\section{RESULTS}

There were 45 patients treated in the period, of whom 38 were included in the study and seven excluded due to incomplete data. Of the analyzed sample, four patients $(10.5 \%)$ were women, with a mean age of 26.25 years, and 34 (89.5\%) male, with a mean age of 28.6 years. There was no statistical difference in age or in relation to gender. Most of the incidents occurred at night, with 13 patients (34.2\%) attended at night and $12(31.6 \%)$ in the early hours. The time of day with less patients admitted was the morning, with two individuals (5.2\%), with no statistical difference. The distribution of months shows a higher incidence in the months of December, with five patients (13.1\%), and February, with seven (18.4\%). The average hospital stay was 13.7 days, being 10.8 days for patients with clinical management and 18.8 days for those undergoing a 
surgical approach, with no statistical difference between these groups $(p=0.112)$.

Closed traumas totaled 23 cases $(60.5 \%)$, of which $21(91.3 \%)$ underwent clinical treatment and two $(8.7 \%)$, surgical. Penetrating trauma occurred in 15 patients (39.5\%), $12(80 \%)$ underwent surgical treatment and three $(20 \%)$, conservative one $(p<0.001)$. In the group of penetrating injuries, stab wounds were the less common, in four patients $(26.7 \%)$, two (50\%) submitted to clinical treatment and two (50\%), to surgical. Among the 11 patients $(73.3 \%)$ with injuries by firearms, ten underwent surgical treatment $(90.9 \%)$ and one, clinical $(9.1 \%)$, with no statistical difference $(p=0.07)$. Figure 1 depicts the stratification of mechanisms between closed traumas.

The diagnosis of renal injury was performed by computed tomography (CT) in 20 patients (52.6\%), and by laparotomy, in 18 (47.4\%). Among those who were diagnosed by CT, 18 (90\%) underwent conservative treatment, and two (10\%) required surgery. In patients whose diagnosis was done through laparotomy, 12 (66.7\%) required surgical intervention, and six $(33.3 \%)$ were treated conservatively $(p<0.05)$.

Through the diagnostic method, it was also possible to know the stage of renal injury, whose distribution is shown in Figure 2.

In 12 cases (80\%) with minor injuries, treatment was conservative, and three (20\%) required some surgery, while among those with major lesions, seven patients $(43.75 \%)$ were treated conservatively and nine $(56.25 \%)$ required surgery $(p=0.157)$. We also compared the major lesions to each other as for the treatment used, surgical or clinical, but without significant differences, as Table 1 shows.

Thirty patients (78.9\%) had associated injuries, 24 (80\%) being intra-abdominal, 12 (40\%) in the chest and two (6.7\%) in the spinal cord. In the group of patients with some associated injury, 14 (46.7\%) required some surgery and 16 (53.3\%) did not. Among the eight subjects who had no associated injury, none required surgery $(p<0.05)$.

Of the 24 patients that had some other abdominal viscera affected besides the kidney, in

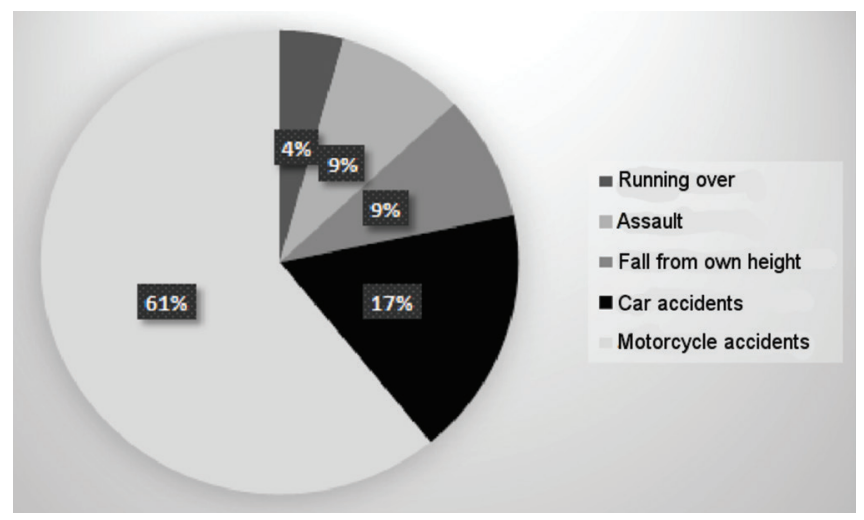

Figure 1. Mechanisms of blunt trauma.

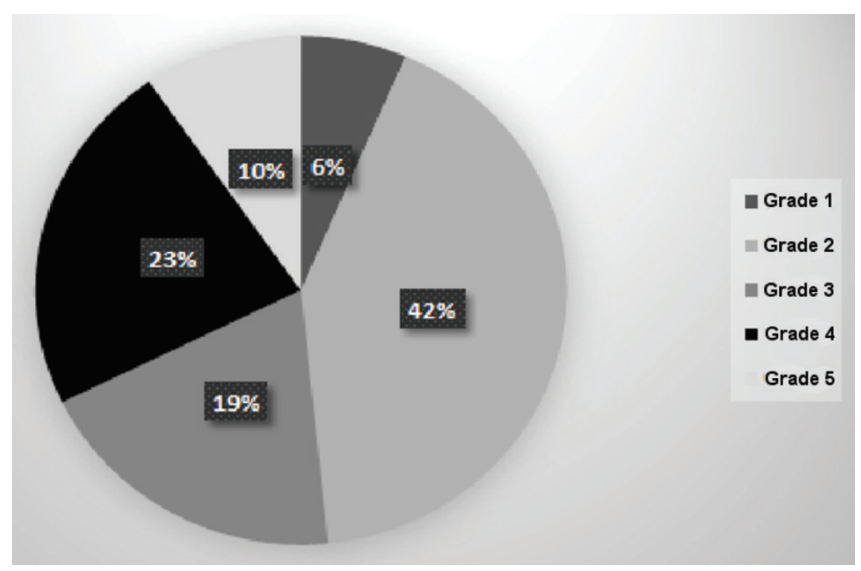

Figure 2. Staging of renal lesions.

$12(50 \%)$ we found only solid viscera lesions, in six (25\%), only hollow viscera lesions, and in six (25\%), both. Of those with involvement of solid viscera, only three $(25 \%)$ required surgical treatment and nine (75\%) were treated conservatively. In six patients with involvement of hollow viscera, four (66.6\%) required surgery and two (33.3\%) had the renal injury treated conservatively. In the group with combination of solid

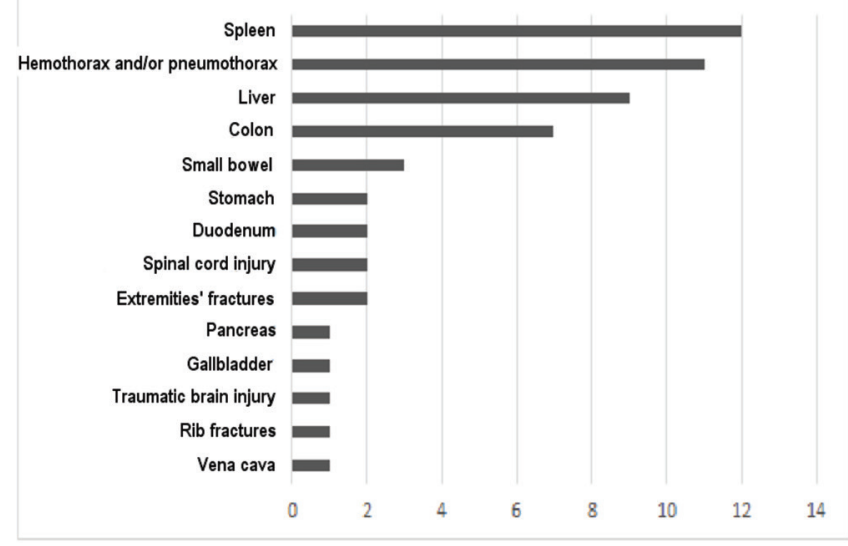

Figure 3. Distribution of associated injuries. 
Table 1. Comparison of major renal lesions.

\begin{tabular}{llcccc}
\hline Stage & \multicolumn{2}{c}{ Surgical treatment } & \multicolumn{2}{c}{ Clinical treatment } & $\mathrm{p}$ \\
& $\mathrm{n}$ & $\%$ & $\mathrm{n}$ & $\%$ & \\
\hline Grade 3 & 3 & 50 & 3 & 50 & \\
Grade 4 & 2 & 28.6 & 5 & 71.4 & \\
Total & 5 & 38.5 & 8 & 61.5 & \\
& & & & & \\
Grade 3 & 3 & 50 & 3 & 50 & \\
Grade 4 & 2 & 28.5 & 5 & 31.5 & \\
Grade 5 & 2 & 66.7 & 1 & 33.3 & 0.49 \\
Total & 7 & 43.7 & 9 & 53.3 & \\
\hline
\end{tabular}

and hollow viscera injuries, all required some surgery of the renal injury $(p<0.05)$. Of the 24 patients with associated abdominal injury, 13 (54.2\%) required some type of intervention, while among the 14 individuals who had no abdominal or pelvic injury, one (7.1\%) required surgery $(p<0.01)$. Associated lesions in other areas showed no statistical difference as for the need or not of surgical treatment for the renal trauma.

Figure 3 shows the types of lesions found. We calculated the data based on the total number of lesions found, not the total number of patients, for a single patient could have more than one lesion.

Clinical treatment was applied in 24 patients (63.15\%) and the remainder required surgical treatment as a primary approach. Nephrorrhaphy was used in six patients (42.9\%) and nephrectomy in eight (56.1\%). Of those who underwent clinical treatment, only one required conversion to surgery to perform nephrectomy.

The overall mortality rate was $10.52 \%$ (4 patients). In the surgical treatment group, 12 patients $(85.7 \%)$ were discharged and two (14.3\%) died. In the clinical treatment group, the outcome was favorable in 22 patients (91.7\%) and two (8.3\%) died for reasons other than renal trauma. There was no statistical difference between the groups ( $p>0.05)$.

\section{DISCUSSION}

Trauma is the third leading cause of death in Brazil and the leading cause of morbidity and mortality among the population under 40 years ${ }^{8}$. The abdominal trauma, specifically, still brings a diagnostic challenge, since there are no reliable signs of intra-abdominal injury, and the anamnesis may be impaired by conditions associated with trauma ${ }^{9}$. Usually, in penetrating trauma the small intestine and liver are affected, while in closed traumas the liver is the most affected organ, followed by the spleen and the kidneys ${ }^{10-12}$. In the latter case, the profile of patients with this type of injury usually follows the same epidemiology of trauma, as seen in our study and in other national and international series $^{3,4,7}$. The occurrences concentrate in the night time, with most held at night (34.2\%) and in the early morning (31.6\%). Other studies on trauma using the same methodology for division of day periods show a difference in the proportion of cases, some with concentration in the night and early morning of $31.1 \%$ to $42 \%^{13,14}$, and others in the afternoon ${ }^{15}$.

Most kidney damage (80-90\%) occur by closed traumas, usually resulting from traffic accidents involving cars, pedestrians and especially motorcycles ${ }^{1,4,16}$. In our study, the closed mechanism involving traffic accidents especially with motorcycles was also the most common, found in $60.5 \%$ of cases, lower values than those referenced in other regions ${ }^{2,3,7,12}$. Penetrating injuries had a higher proportion of affected (39.5\%) compared to other regions of the country, although to a lesser extent in relation to closed trauma. They were for the most part (73.3\%) caused by firearms. A Curitiba trauma service even showed values much higher than the national 
average, around $84.8 \%$ of penetrating trauma, mostly by firearms ${ }^{17}$. This may be the result of a selection bias due to population profile attended by the hospital, or merely the result of urban violence in one of the cities with the highest homicide rates in the country. In other cities, penetrating injuries accounted for $10-20 \%$ of the causes of renal trauma.

Because of the kidneys' anatomical position, which provides protection in blunt trauma, renal lesions are indicative of high-energy trauma and usually come with injuries to other parts of the abdomen or other body systems ${ }^{11}$. In our study, 30 patients (78.9\%) had at least some other associated injury, mostly (80\%) represented by other abdominal viscus and $40 \%$ represented by lesions in the thorax. The literature does not reach an agreement regarding injury association, and the values found differ depending on the study. Our results are equivalent to $78.8 \%$ of cases found in the city of Sorocaba and $65.1 \%$ in Coimbra ${ }^{4,7}$, but are higher than the values found by other authors, who reported rates between 13-34\% ${ }^{12}$. In agreement with other studies, liver and spleen are among the major abdominal associated injuries $s^{4,9,16}$.

Currently, conservative treatment is recommended for solid viscera injury. For its adoption, however, a hospital structure is required to dispose of ICU beds, professionals with experience in trauma and the patient should be hemodynamically stable and without active bleeding signals. Computed tomography becomes indispensable for this type of treatment, since it can diagnose associated abdominal injuries and reveal exactly the staging of renal injuries. Major renal lesions have a higher chance of needing surgery compared with minor ones. The staging alone does not indicate intervention, but allows damage estimation and an improved interventional programming, if necessary, either by surgery or by angioembolization ${ }^{3-5,11,12,17,18}$. The tomographic diagnosis was used in 20 patients (52.6\%), and of these, 18 (90\%) were treated conservatively. Of the 18 patients (47.4\%) who were diagnosed during surgery, only six (33\%) had conservative management. There are few studies on the diagnostic methods used to identify kidney injury. One study observed CT use in $33.3 \%$ of cases, the other $66.6 \%$ requiring laparotomy for diagnosis 4 . Another found diagnosis by CT in $41 \%$ of cases $^{18}$. We found no data in the literature comparing the use of diagnostic methods with the type of treatment employed.

The higher the degree of injury, the greater the chance of need for surgical intervention. Overall, injury grades 1 and 2, the most common, are managed conservatively, while larger lesions require a surgical procedure'. In our study, the profile of these lesions is different from that found in other studies. We found 16 patients (52\%) had high-grade lesions, seven $(43.7 \%)$ of whon being treated conservatively, and 15 (48\%) had low-grade lesions, with 12 (80\%) receiving conservative treatment. Another trauma service in Curitiba has a proportion of $51.4 \%$ low-grade and $49.6 \%$ high-grade lesions but virtually all (90.9\%) were surgically treated ${ }^{17}$. These are data divergent from other articles, but it is worth mentioning that in that study about $90 \%$ of traumas were penetrating ${ }^{17}$. One of the questions in the literature revolves around the management of 4 and 5 degree injuries. In our study, there was no significant difference on who required surgery or were medically treated. Other authors seek to stratify the need or not of surgery through imaging methods, however, without consensus yet ${ }^{18}$.

The conservative approach, as seen in our study, is associated with lower morbidity and a shorter hospital stay, resource saving, avoiding surgical complications, avoiding the possible loss of the involved organ and allowing an earlier return to normal activities. The mean duration of hospitalization in the literature ranges from less than six days ( 2 to $23)^{4}$ to 16.5 days $^{7}$.

The lesions who underwent surgical treatment occurred in patients with classical indication for laparotomy, such as hemodynamic instability, peritonitis or in cases where the performance of imaging was not indicated $2,3,12,13$. The association of other abdominal injuries also increases the chance of surgical treatment ${ }^{12}$. The mortality rate was $10.5 \%$ and occurred 
in two patients in the clinical treatment group (8.3\%) and in two patients in the surgical group (14.3\%). None of the deaths occurred due to the renal trauma itself, being caused by other associated injuries. Other authors reported mortality rates ranging from $6.6 \%$ to $26 \%$, also related to associated injuries ${ }^{17,18}$.

In conclusion, the profile of patients with renal trauma treated at the Evangelical Hospital in Curitiba-PR is represented by young men, victims of road accidents involving motorcycles, in particular occurring during the night and early morning. Most injuries were treated conservatively, with a low rate of conversion to surgery. Patients who required surgical management for the most part had more severe kidney injuries and/ or associated lesions in some abdominal viscus. The hospital stay was lower in the group treated conservatively and the deaths that occurred were due to other associated injuries and not to renal trauma.

\title{
R E S U M O
}

\begin{abstract}
Objetivo: estudar o perfil das vítimas de traumas renais submetidos a tratamento cirúrgico e clínico em um hospital de Curitiba. Métodos: estudo transversal quantitativo analítico retrospectivo de pacientes com trauma renal admitidos no Hospital Universitário Evangélico de Curitiba entre fevereiro de 2011 e janeiro de 2014. Resultados: fizeram parte do estudo 38 pacientes, sendo quatro mulheres e 34 homens, com média de idade de 28,4 anos. A maior parte dos traumas $(60,5 \%)$ foi decorrente de mecanismo fechado, em especial acidentes automobilísticos envolvendo motos, tratados de maneira conservadora na maior parte dos casos. Os pacientes que necessitaram de tratamento cirúrgico possuíam lesões renais graves ou alguma outra lesão associada, geralmente intra-abdominal. 0 tempo de internamento foi menor no grupo de tratamento conservador (10,8 dias) em relação ao grupo de tratamento cirúrgico (18,8 dias), assim como a mortalidade também foi menor no grupo de tratamento conservador (8,3\%) comparada ao cirúrgico (14,3\%). Nenhuma morte foi relacionada à lesão renal em si. Conclusão: os pacientes com traumatismo renal neste estudo foram homens jovens, vítimas de acidentes automobilísticos com motos, ocorrendo durante a noite e madrugada. A maioria das lesões foi tratada de modo conservador.
\end{abstract}

Descritores: Ferimentos e Lesões. Rim/Lesões. Traumatismos Abdominais. Traumatismo Múltiplo. Traumatologia.

\section{REFERENCES}

1. Pereira Júnior GA, Lovato WJ, Carvalho JB, Horta MFV. Abordagem geral trauma abdominal. Medicina (Ribeirão Preto). 2007;40(4):518-30.

2. Advanced Trauma Life Support for Doctors. ATLS Student Course Manual. $8^{\text {th }}$ ed. Chigaco: American College of Surgeons; 2008. p.111-30.

3. Silva LF, Teixeira LC, Rezende Neto JB. Abordagem do trauma renal. Rev Col Bras Cir. 2009;36(6):519-24.

4. Grillo FRC, Oliveira ARB, Miranda M, Colombo R, Dib Neto JC, Gun S. Trauma renal. Rev Fac Ciênc Méd Sorocaba. 2004;6(2):12-6.

5. Aragona $F$, Pepe $P$, Patanè $D$, Malfa $P$, D'arrigo $L$, Pennisi M. Management of severe blunt renal trauma in adult patients: a 10-year retrospective review from an emergency hospital. BJU Int. 2012;110(5):744-8. Epub 2012 Feb 7.

6. Cury J, Mesquita JLB, Pontes J, Oliveira LCN, Cordeiro M, Coelho RF. Trauma urológico. Rev Med (São Paulo). 2008;87(3):184-94.
7. Nunes P, Maia N, Parada B, Rolo F, Mota A. Traumatologia renal nos HUC. Experiência de treze anos. Acta Urol. 2004;21(1):45-54.

8. Ministério da Saúde. Mortalidade proporcional por grupos de causas [Internet]. Brasília; RIPSA; 2011. [acesso em 20 mai 2014]. Disponível em: http://tabnet.datasus.gov.br/cgi/tabcgi.exe?idb2012/c04.def

9. Farrath S, Parreira JG, Perlingeiro JAG, Solda SC, Assef JC. Fatores preditivos de lesões abdominais em vítimas de trauma fechado. Ver Col Bras Cir. 2012;39(4):295-301.

10. Leite S, Taveira-Gomes A, Souza H. Lesão visceral em trauma abdominal: um estudo retrospetivo. Acta Med Port. 2013;26(6):725-30.

11. Sandler CM, Amis Jr. ES, Bigongiari LR, Bluth El, Bush WH, Choyke PL, et al. Abordagem diagnóstica do trauma renal. CBR. [acesso em 2014 jun 6]; 2(2):783-787. Disponível em: http://cbr.org.br/ wp-content/biblioteca-cientifica/v2/02_02.pdf

12. Fonseca Neto $\mathrm{OCL}$, Vasconcelos R. Tratamento não cirúrgico do traumatismo renal contuso. JBM. 2013;101(6):35-7. 
13. Lima SO, Cabral FLD, Pinto Neto AF, Mesquita FNB, Feitosa MFG, Santana VR. Avaliação epidemiológica das vítimas de trauma abdominal submetidas ao tratamento cirúrgico. Rev Col Bras Cir. 2012; 39(4):302-6.

14. Zandomenighi RC, Mouro DL, Martins EAP. Ferimento por arma branca: perfil epidemiológico dos atendimentos em um pronto socorro. Rev Rene, Fortaleza. 2011;12(4):669-77.

15. Broska Júnior $C A$, De Folchini $A B$, Ruediger RR. Estudo comparativo entre o trauma em idosos e não idosos atendidos em um hospital universitário de Curitiba. Rev Col Bras Cir. [Internet]. 2013 [acesso em 2014 jun 6];40(4):281-6. Disponível em URL: http://www.scielo.br/scielo.php?pid=\$0100-6991 $2013000400005 \&$ script=sci_abstract $\&$ tlng $=p t$

16. Howes N, Walker $\mathrm{T}$, Allorto NL, Oosthuizen GV, Clarke DL. Laparotomy for blunt abdominal trauma in a civilian trauma service. S Afr J Surg. 2012;50(2):30-2.
17. Grareschi BLV, Stahlschmidt CMM, Becker K, Batista MFS, Buso PL, Von Bahten LC. Análise epidemiológica de politraumatizados com lesões renais em um hospital universitário. Rev Col Bras Cir. 2015; 42(6):382-5.

18. Reis LO, Kim FJ, Moore EE, Hirano ES, Fragas GP, Nascimento B, et al. Atualização da classificação e tratamento das lesões renais complexas. Rev Col Bras Cir. 2013;40(4):347-50.

Received in: 17/05/2016

Accepted for publication: 24/08/2016

Conflict of interest: none.

Source of funding: none.

\section{Mailing address:}

Cesar Augusto Broska Júnior

E-mail: cesar_broska41@hotmail.com cesar_broska41@gmail.com 